\title{
SPED - Public Digital Bookkeeping System: influence in the economic-financial results declared by companies
}

\author{
SPED-Sistema Público de Escrituração Digital: influência nos resultados \\ econômico-financeiros declarados pelas empresas \\ SPED-Sistema Público de Escritura Digital: influencia en los resultados
económicos-financieros declarados por las empresas
}

\author{
Aldy Fernandes da Silva ${ }^{1}$ \\ Gustavo Rique Pinto Passos ${ }^{2}$ \\ Mauro Fernando Gallo ${ }^{3}$ \\ Marcos Reinaldo Severino Peters ${ }^{4}$
}

Received on June 14, 2012 / Approved on April 3, 2013

Responsible Editor: Ivam Ricardo Peleias, Dr.

Evaluation process: Double Blind Review

\begin{abstract}
By deploying the Public Digital Bookkeeping System (SPED), tax administration seeks to increase the subjective perception of risk between taxpayers and reduce the tax gap. The objective of this research is to verify whether the implementation of Accounting SPED had an influence on the economic and financial results declared by companies (gross revenue and net profit). The null hypothesis of the research - the lack of relationship between these variables - was tested through the regression model with panel data. The sample was selected from the 500 largest companies listed in the database Best and Biggest, by Exame Melhores e Maiores magazine. The data collected comprise financial statements of these companies
\end{abstract}

on the calendar years 2004 to 2009. Regression models were estimated using random effects, with unbalanced panels. The Accounting SPED showed significance in all regression models of gross revenue and net profit, allowing the rejection of the null hypothesis of no relationship between these variables. Finally, according to the analysis models of tax evasion exposed in the literature review, considering that the Accounting SPED increases the effectiveness and efficiency of auditing mechanisms of the tax administration, an increase on the economic and financial results declared by companies of the sample was expected, which was confirmed in research.

Keywords: Economic and financial results. Tax administration. SPED. Panel data.

1. Doctor in Production Engineering, University of São Paulo. Professor of FECAP University Center. [aldy@fecap.br]

2. Master in Accounting Sciences, FECAP University Center. [grp.passos@gmail.com]

3. Doctor in Controllership and Accountancy, University of São Paulo. Professor of FECAP University Center. [mauro.gallo@fecap.br]

4. Doctor in Controllership and Accountancy, University of São Paulo. Professor of FECAP University Center.

[marcospeters@marpet.com.br]

Authors' address: Av. Liberdade, 532, Liberdade, São Paulo, SP CEP. 01502-001 - Brazil 


\section{RESUMO}

Ao implantar o Sistema Público de Escrituração Digital (SPED), a administração tributária brasileira buscou ampliar a percepçáo de risco subjetivo entre os contribuintes, e reduzir a brecha fiscal. Esta pesquisa tem como objetivo verificar se a implementação do SPED Contábil teve influência sobre os resultados econômicofinanceiros declarados pelas empresas (lucro líquido legal e faturamento bruto). A hipótese nula da pesquisa - ausência de relação entre essas variáveis - foi testada por meio de um modelo de regressão com dados em painel. A amostra foi selecionada a partir da lista das 500 maiores empresas do banco de dados da revista Exame Melhores e Maiores. Foram coletados os dados referentes às demonstraçóes financeiras dessas empresas relativas aos anos-calendário de 2004 a 2009. As regressões foram efetuadas por meio de modelos com efeitos aleatórios, com a utilização de painéis desbalanceados. O SPED Contábil apresentou significância nos modelos de regressão do faturamento bruto e lucro líquido legal, permitindo a rejeição da hipótese nula. Por fim, de acordo com os modelos de análise da sonegação fiscal expostos na revisão bibliográfica, considerando-se que o SPED Contábil aumenta a eficácia e a eficiência dos mecanismos de auditoria da administração tributária, esperava-se um incremento nos resultados econômico-financeiros declarados pelas empresas integrantes da amostra, o que foi confirmado na pesquisa.

Palavras-chave: Resultados econômicofinanceiros. Administração tributária. SPED. Dados em painel.

\section{RESUMEN}

Al implantar el Sistema Público de Escritura Digital (SPED), la administración tributaria busca la percepción de riesgo subjetivo entre los contribuyentes y reducir la brecha fiscal. Esta investigación tiene por objetivo averiguar si la implementación del SPED Contable influyó sobre los resultados económico-financieros, declarados por las empresas (lucro beneficio neto y facturación bruta). La hipótesis nula del estudio-ausencia de relaciones entre estas variables- se comprobó a través del modelo de regresión con los datos en panel. La muestra se seleccionó a partir de la lista de las 500 mayores empresas de la base de datos de la revista Exame Melhores e Maiores. Se recopilaron datos referentes a las demostraciones financieras de esas empresas en relación a los años naturales de 2004 hasta 2009. Las regresiones se realizaron a través de los modelos con efectos aleatorios, con la utilización de paneles sin balance. El SPED Contable resultó significativo en los modelos de regresión de la facturación bruta y beneficio neto legal, permitiendo el rechazo de la hipótesis nula. Por último, de acuerdo a los modelos de análisis de evasión de impuestos expuesta en la revisión bibliográfica, teniendo en cuenta que el SPED Contable aumenta la eficacia y la eficiencia de los mecanismos de la auditoría de la administración tributaria, se esperaba un aumento sobre los resultados económico financieros declarados por las empresas participantes en la muestra, lo cual quedó confirmado en el estudio.

Palabras clave: Resultados económico-financieros. Administración tributaria. SPED. Datos en panel.

\section{INTRODUCTION}

The issue of public finances unbalance, resulting from the continue increase of expenditures without a revenue counterpart, is a determining factor for the low growth rate of the economy and for the limited public investment. Considering the limitation of the tax balance model based on the systematic increase of tax burden, the government has to urgently increase the efficiency of tax collection, which is directly related to fighting tax evasion and reducing collection and tax compliance costs.

The Public Digital Bookkeeping System (SPED), created by Decree no. 6022, as of January 22,2007 , is included in such context (BRASIL, 2007a). Comprised of three main projects Digital Accounting Bookkeeping (Accounting 
SPED), Digital Tax Bookkeeping (Tax SPED), and Electronic Invoicing (NF-e) -, this system is an integrated initiative of the federal, state and municipal tax administrations, consisting of the modernization of the current systematic in the compliance with accessory obligations by companies. After its deployment, taxpayers will provide information to the tax administration exclusively through digital documents.

With this new system, the intention is to promote the integration of tax administrations, through standardization and sharing of accounting and tax information, observing legal restriction; to rationalize and to uniformize the accessory obligations for taxpayers, with the establishment of the single transmission of different accessory obligations of different inspecting agencies; to speed up the identification of tax violations, by improving process control, quick access to information, and more effective inspection of operations, crisscrossing data and conducting electronic audits.

The models of tax evasion evaluation (ALLINGHAM, SANDMO, 1972; RICARDO, MENDONÇA, WANDERLEY, 2005 ; SIQUEIRA, 2004; VASIN, VASINA, 2002) are based on the hypothesis that the taxpayer decides which part of his revenue he will state to the tax administration, considering the probability of being audited, and such probability, in turn, depends on the government inspection efforts.

By deploying the SPED, the government seeks to improve the efficiency of its inspection mechanisms and to reduce tax evasion. The expectation is that, upon increasing the probability of detecting tax violations, taxpayers will state a bigger portion of their revenue, or even the whole revenue. Under such circumstances, this work tries to answer the following question: did the new system for the compliance with accessory obligations - Accounting SPED - influence the economic-financial results declared by companies?

The general objective of this research is to empirically investigate the existence of a relation between the Digital Accounting Bookkeeping (Accounting SPED) and the economic-financial results declared by companies (measured by the gross revenue and the net profit). More specifically, our intention is to check, through an empirical research, whether the variation of the gross revenue and the net profit in the calendar years of 2008 and 2009, against the period 2004 to 2007 ,

To accomplish this objective, the following hypotheses were formulated: $\mathbf{H 1}$ - there is a relation between the Accounting SPED and the gross revenue declared by companies; $\mathbf{H 2}$ - there is a relation between the Accounting SPED and the net profit declared by companies. The hypotheses will be statistically tested through an estimation model for panel data, which has both cross-section and time-series dimensions.

According to Barbosa and Barbosa (2004), the Brazilian tax system shall be structured in order to contribute to its economic and social development, in addition to financing government expenditures. Tax evasion has noxious effects on the efficiency and fairness of the tax system, and therefore tax collection polices should focus on detecting and enforcing sanctions to evasion activities, and, on the other hand, it should create incentives to the compliance with tax obligations. In a country such as Brazil, with huge social needs and lacking public investments, the tax collection issue is a very relevant topic in studies about public administration and social management.

By empirically verifying alterations in the behavior of companies regarding their tax responsibilities, resulting from the new system to comply with accessory obligations (SPED), this research might provide important subsidies for planning and executing tax collection polices and to fight tax evasion.

\section{THEORETICAL REFERENCES}

\subsection{Efficiency of the tax administration}

Bergamini Júnior (2001) points out that the Brazilian economic authorities, upon creating measures to improve the government 
performance, ended up prioritizing the balance of accounts, with focus on tax collection. To Campello (2003, p. 54), the concept of tax efficiency should not only consider the potential value of tax collection, but the "efficient degree of the tax base exploration", called "necessary exploration". Thus, the pursuit for efficiency in tax collection should not be focused on the increase of revenue, but rather on reducing the difference between realization and the exploration potential.

In general, the potential tax collection is equal to the maximum collection that the Tax Administration (TA) would obtain if all taxpayers correctly complied with their respective tax obligations, i.e., it corresponds to the hypothetical situation in which there is no tax evasion. A way to appraise the TA efficacy would be through the proportion between the effective tax collection and the potential tax collection (tax gap).

To attain the objective of reducing the tax gap, the TA plays the inspection role by means of two strategies: internal audit and external audit. The first, also known as documental audit, is based in crisscrossing information available in the TA control systems and in verifying their consistence. On the other hand, the external or field audit requires a higher level of investigation and specialization in detecting tax frauds.

The use of new Information and Communication Technologies (ICT) allows the Tax Administration to access a bigger volume of information on taxpayers in a quicker way. Considering that the internal audit allows a larger coverage than the external one, with results about the mass of taxpayers, the quality and quantity of information available by intensively using the ICT tend to increase the TA efficacy in its mission of expanding the voluntary compliance. This happens because the internal inspection allows optimizing human and financial resources, thus reducing the tax administration costs. The deployment of the SPED is the best example of this new context of TA performance, with possible implications on the organizational design and functional attributions, in view of the expansion of the control performed by the digital audit activity.

To Sayeg (2003, p. 5), the contemporary economic-marketing system, "supported on increasingly complex information systems", makes the tax administration task more difficult by "creating a gap between the inspecting agency potential to detect tax evasion and the taxpayer potential to perform it". Such fact results in the need of tax administrations showing not only an evolution of the organizational structure, but also of the technical qualification of tax agents, to permanently being qualified to face the organizational and technological complexity in business relations. The speed of transactions and their dematerialization, intrinsic to the electronic business model, have set up a new paradigm for tax authorities, in regard to their duty of detecting and repressing tax evasion.

Given these circumstances, three elements become more relevant in the discussion involving the tax evasion detection issue: technology, organizational design and velocity. The intensive use of information technology becomes indispensable to attain the goal of having an efficient/effective tax collection. In addition, it is also necessary to restructure the organizational model of tax administrations to inspect big economic groups with national and international coverage - a natural result of the globalization process was the intensification of the consolidation of various economic sectors, with the consequent appearance of Brazilian multinational companies. The inspection of such companies depends on a higher exchange of information amongst decentralized federal tax agencies and of these with state and municipal tax administrations. Both dimensions (information technology and organizational structure) are connected, and the performance of the velocity vector directly depends on them.

In addition to the efforts of large scale taxpayers' inspection, in general, the tax administration is investing in information technology and data sharing to increase the 
efficiency of the internal audit of financial statements, and to more quickly identify errors and omissions in the information provided. Based on the models of tax evasion evaluation, it is expected that the SPED deployment results in an increase of the tax base declared by companies, since this new accessory obligation system has the aim of expanding the perception of the taxpayer about the probability of being audited.

\subsection{Tax compliance}

Although taxes have a coactive nature, they can't only be enforced based on coercion. In contrast, the strategy adopted by most of tax administration is based on incentives to the volunteer compliance. The success of the strategy of increasing tax compliance rates and, consequently, reducing the tax gap in a way depends on the capacity of the tax administration to analyze the taxpayers' behavior and to identify factors that induce them to act in noncompliance with tax laws. Once those factors are known, it is possible to deploy more efficient tax collection policies in terms of tax evasion reduction.

\subsection{Tax evasion}

According to Siqueira and Ramos (2005), in economic terms, tax evasion results from the asymmetry of information between taxpayer and the tax administration, regarding the variables that define the tax base (revenue, sales, profits, wealth, among others). I.e., the tax administration cannot check the actual value of the taxpayer's tax base, and thus it cannot calculate its actual tax responsibility. Hence, taxpayers might take advantage of the imperfect information the tax administration has about their responsibility, and thus deceive taxation. The tax audit tries to correct this information asymmetry and find out the actual tax base of taxpayers.

According to Pohlmann and Iudícibus (2006), the tax evasion issue can be analyzed through the agency theory. In general, an agency relation is established through a contract in which the agent performs certain activities in benefit and according to the objectives of the principal. From this contract, there is a delegation of authority to the agent so that he makes decisions on behalf of the principal. However, if both parties of the relation try to maximize their utility, in some situations there will be a conflict of interests.

In case of taxes registered through homologation, the State (principal) delegates to the taxpayer (agent) the task of verifying and paying the tax, regardless of the tax authority action. Therefore, the State tries to maximize its utility, by reducing its administrative costs and gaining agility in collecting taxes. Its main focus becomes the incentive to tax obedience. The taxpayer (agent), in turn, tries to optimize his utility and wellbeing through mechanisms that reduce his tax burden, and allow an increase of the net revenue. In view of the potential losses of tax collection to which the State is subject in this agency relation, as the result of probable income omissions practiced by the taxpayer, the State (principal) is obliged to make a tax effort to control and monitor the agent (POHLMANN; IUDÍCIBUS, 2006).

In addition to imposing an additional cost to the tax administration, resulting from the audit activities, tax evasion strongly interferes with the tax system and economic activity functioning. The occurrence of tax evasion hinders the performance of tax administrations in their mission of ensuring the financing of the State, affecting the economic efficiency (disloyal completion), reducing the fairness and justice of the tax system, and jeopardizing the tax collection policies. Pohlmann and Iudícibus (2006) say that the theory of games can be used to analyze the conflict of interests between the tax administration and the taxpayer. The main aim of this theory is to determine the optimum strategy for each player. Therefore, in a non-cooperative game between the State and the taxpayer, the later adopts a strategy to maximize his revenue - via understatement - while the former aims to maximize its tax collection.

Sayeg (2003) argues that the effort to reduce tax evasion should not only be focused on detection, but should also consider three other variables: prevention, legitimation and ethics. 
To that end, tax administration should invest in actions related to tax evasion prevention, tax legitimation and diffusion of ethical values among taxpayers, as a way to ensure a higher degree of volunteer compliance with tax obligations.

In regard to prevention, actions should focus on tax education and on the review of the rules in force with the aim of closing the gaps used for tax evasion. Legitimation can be attained through a simple tax system, which allows the taxpayer to clearly know the tax burden to which his revenue is submitted, and the adoption of mechanisms ensuring transparency in the rendering of government accounts, in regard to the application of the resources obtained with tax collection. This transparency allows to evaluating the effectiveness of the tax system in ensuring the social wellbeing and a higher awareness of taxpayers about the social role of taxes, which will have positive results in terms of reducing ethical and behavioral deviations.

To Olivo, Gozzi and Cavalcanti (2008, p. 61), there is a generalized perception in the Brazilian society of the illegitimacy of the tax burden, "not of the tax itself, since the State needs resources to accomplish its obligations", but mainly of the very high costs of tax compliance by taxpayers, "worsened by wastes and incompetency of the State in making a good management of such resources, resulting in lousy services to the society". Therefore, a considerable portion of taxpayers refuses to accomplish their tax obligations, with tax suppression or evasion mechanisms, which the authors regard as a tax civil disobedience.

Tp Maia et al. (2008, p. 51), a determining factor for the high cost of compliance "is the instability of the Brazilian tax rules and the complexity created by the amount and constant changes in the legislation". Souza, Tannuri-Pianto and Santos (2008, p. 78), when analyzing the impact of the tax structure on the import tax evasion, point out that in developing countries the "existence of high charges and a complex tariff structure marked by a myriad of exemptions" ends up hindering the control of the tax administration and facilitating tax evasion. Given such circumstances, it is reasonable to infer that the simplification of the tax system, in addition to reducing the compliance and tax collection costs, would result in the expansion of the tax collection base, thus creating the opportunity of reducing tax rates.

\subsubsection{Models of analysis of tax evasion}

The first model of analysis of tax evasion was developed by Allingham and Sandmo (1972). The adopted thesis is that the behavior of the taxpayer is the result of a rational decision between the evasion costs and benefits. The taxpayer decides which portion of his revenue he wants to invest in the evasion activity. If he is not willing to take any risk, he declares his whole revenue; in contrast, he declares only a portion and decides to take the risk of being audited and getting a fine. According to this model, the decision of evading depends on the audit probability and on the penalty rates.

This model of taxpayer evasion decisions analysis is based on the following assumptions: taxes and penalties are proportional, the audit probability is constant, and only an evasion manner is available (the understatement of the taxable revenue). Furthermore, "it is assumed that the taxpayer follows the theory of expected utility and is perfectly amoral, i.e. he takes decisions in exclusive obedience to the consequences for the net income" (SIQUEIRA, RAMOS, 2006, p. 401).

However, various extensions of this model, based on alternative hypotheses, were developed, and the results show that tax evasion cannot be exclusively explained by the financial generated by the low degree of law enforcement. The responsibility for the usually observed low degree of compliance with the tax law cannot be only attributed to the government enforcement activities; i.e., the basic model, based on the theory of expected utility, is insufficient to explain this behavior (SIQUEIRA, RAMOS, 2005).

Also in contrast with Allingham and Sandmo (1972), researchers argue that individuals 
usually do not face the probability of a fixed and random audit. In fact, the tax authority often uses information from income tax return forms in order to strategically determine who to audit, so that the audit probability becomes endogenous and partially depends on the behavior of the taxpayer and on the tax authority. Brazil, for instance, uses the information from taxpayers' income tax return forms and crisscross it with other sources of information to define its fine screening parameters and decide who should be audited (SIQUEIRA, RAMOS, 2005).

All the hypotheses of this basic model were criticized, and theoretical models based on alternative hypotheses were developed in the attempt to formally introducing other factors that seem to be relevant for the individual decision of evading, such as the job opportunity (PENCAVEL, 1979; COWELL, 1981); complementary schemes of tax evasion (CROSS, SHAW, 1982); alternative penalties and nonlinear rates (KESSELMAN, 1989; PENCAVEL, 1979); complexity and uncertainty of tax parameters (ALM, 1988; SCOTCHMER, SLEMROD, 1989); services provided by the government - taxpayers pay more taxes, insofar as the government shows to be more effective in offering services in exchange for taxes (COWELL, GORDON, 1988)

An alternative factor that showed to be relevant for the individual decision to pay taxes - or not to evade taxes - was the perception in regard to the contribution of other taxpayers (ALM, 1988), which is directly related to the perception of fairness and justice of the tax system. Another important factor evaluated was the positive response to incentives given to taxpayers who were audited, and said they would comply with their tax obligations (FALKINGER, WALTHER, 1991). Although such extensions make models more robust and faithful to the reality, the conclusions in general are the same of Allingham and Sandmo (1972), only with punctual differences in terms of quantity of enforcement parameters (SIQUEIRA, RAMOS, 2005).

There are also some works that expand the basic model of individual decision, introducing some behavioral and motivational aspects regarded as explicit by other social sciences. Other approaches considering factors such as behavioral deviations, social and situational characteristics, social contexts and attribution theory have been applied with a certain degree of success.

The previous observations offer an analytical structure to address some relevant aspects of the tax evasion, suggesting causes and possible remedies, but they have not been sufficient to analyze the phenomenon in its whole complexity. Obviously, the response is not only found in marginal changes in the enforcement practice. However, as social and moral attitudes - which certainly have a very important role are very slow in promoting the necessary changes, and are not easily affected by public policies, to study the standard enforcement system, based on the combination audit plus penalty, still remains crucial. Empirical evidences suggest that a more strict enforcement system (higher probability of detection and punishment) should probably induce to a higher obedience (SIQUEIRA, RAMOS, 2006).

Alm and Mckee (2006) developed experimental models to observe the taxpayer's behavior based on the information of the probability of being audited. The experiment consisted of informing a group of taxpayers, before submitting their income tax return form, that they would be audited. Another group was previously informed that they would not be audited. Both groups were informed about the audit effectiveness (percentage of understatements detected). The experiments results showed an increase of the volunteer compliance among taxpayers with the prior information that they would be audited, and the reverse effect among those informed that they would not be audited. Based on such results, authors say that an increase of the audit probability, associated to a higher effectiveness in detecting violations, has a positive effect on the volunteer compliance.

Slemrod (2006) says that tax evasion is an information problem, and that the progress of technological solutions is allowing a more 
efficient information processing, with potential to revolutionize the relation between taxpayers and the tax administration. The Public Digital Bookkeeping System (SPED) is included in this context. This is a project that was created by Decree no. 6022, as of January 22, 2007 (BRASIL, 2007a), and which is part of the Federal Government Growth Acceleration Program (PAC 2007 - 2010). This project has the mission of rationalizing and simplifying the compliance with accessory obligations by taxpayers through the digital certification of documents, reducing compliance and tax administration cots, and perfecting mechanisms to fight tax evasion.

\subsection{Public Digital Bookkeeping System (SPED)}

In general, the deployment of the SPED consists of the modernization of the current accessory obligation compliance system, transmitted by taxpayers to the tax administrations and to the inspecting agencies, using the digital certification to sign electronic documents, thus ensuring the legal validity of such documents only in their digital form. It is composed of three major subprojects: Digital Accounting Bookkeeping, Digital Tax Bookkeeping and the NF-e - National Environment.

According to the Brazilian Internal Revenue Dept. (SPED, 2009), its deployment will provide the following benefits: reduction of costs with the accessory obligations rationalization and simplification; standardization of information the taxpayer provides to the various federation units; stronger control and inspection through the exchange of information among tax administrations; fast access to information; reduction of administrative costs; improvement o information quality; improvement of tax evasion fighting. Some of such benefits, such as the reduction of fraud risks and operational costs, have been described in the literature as pointed out in Geron et al. (2011).

The focus of this work is the Digital Accounting Bookkeeping (ECD0, the accounting pillar of the SPED. In a simplified way, it comprises the generation of electronic accounting books by using a standard layout file, and digitally signed using a digital certificate. Instituted by the RFB Normative Instruction 787 as of 11/19/2007 (BRASIL, 2007b), the ECD covers the following books: General Journal; Journal with Summary Bookkeeping (related to the ancillary book); Ancillary Journal; Ancillary Ledgers; Book of Daily Balance Sheets and Balance Sheets.

The digital file in the format specified in the RFB Normative Instruction no. 787/07 (BRASIL, 2007b) is generated from the company's accounting system. This file is then submitted to the Validating and Signing Program (PVA) provided by the SPED. In the PVA, the taxpayer shall execute the following procedures: validation of the file containing the bookkeeping; digital signature of the book by the legal responsible person and by the accountant; generation and signature of the request for authentication intended to the commercial registry of its jurisdiction, through the identification of the authentication fee slip (provided by the commercial registry). After signing the bookkeeping and the request, the file can be transmitted to the SPED. Upon receiving the ECD, the SPED provides an extract (request, Opening Document and Closing Document), and provides it to the competent commercial registry, which will electronically authenticate the book.

The RFB Normative Instruction no. 787, as of November 19, 2007 (BRASIL, 2007b), amended by the RFB Normative Instruction no. 926/2009 (BRASIL, 2009), upon regulating the Digital Accounting Bookkeeping, has determined its obligatory use by companies subject to the differentiated tax monitoring system - RFB Ordinance no. 11.211/2007 (BRASIL, 2007c), in relation to the generator fact occurred from $01 / 01 / 08$, with delivery until the last working day of June 2009; in relation to the generator fact occurred from $01 / 01 / 09$ on, the same provision is applicable to all companies subject to the Income Tax based on the actual profit.

To Duarte (2009, p. 130), the major challenge of the Accounting SPED is "to have a coherent, actual and righteous accountancy; 
electronically auditable by the company and by the Tax Administration". The authors points out that, conceptually, the ECD can be interpreted as the single transformation of accounting books into digital documents. However, such transformation will bring out consequences for the whole process of information production and utilization. The operational accounting and tax bookkeeping works tend to increasingly reduce, due to the utilization of integrated management systems (ERP - Enterprise Resource Planning), without which it is nearly impossible to take part of the SPED. The accountants are now performing activities more oriented to the managerial accountancy and to tax planning. The tax administration, in turn, will have a quicker access to higher quality and reliable information, thus increasing the efficiency of its inspection mechanisms.

\section{RESEARCH METHODOLOGY}

To attain the proposed objective, a theoretical and empirical type research was conducted. The methodology used was the archival empirical per sampling methodology, "in which a data sample regarding a certain studied universe is extracted and analyzed" (POHLMANN, IUDÍCIBUS, 2006, p. 9). This kind of research is based on a theoretical referential material, from which the statements that will be confronted with the studied reality are extracted.

To elaborate this referential material, a bibliographic research was initially carried out with the aim of selecting, analyzing and interpreting the theoretical contributions related to the tax matter. In the second step, a documental research on the SPED legislation was conducted, and at last an empirical treatment of secondary data extracted from the Exame Melhores e Maiores magazine (2010) was performed.

\section{I Population, sample and collected data}

The population researched comprised all the companies that were subject to the differentiated economic-tax monitoring in the calendar year of 2008, pursuant to the RFB Ordinance no. 11211/07 (BRASIL, 2007c), and thus obliged to submit the ECD on June 30, 2009. Data regarding the financial statements of these companies for the calendar years 2004 to 2009 were collected. Thus, a sample with data extracted from the financial statements submitted in the previous period (2004 to 2007) and after the introduction of the Accounting SPED were obtained, allowing the comparison of dependent variables behavior (gross revenue and net profit) in both periods.

The sample was taken from the list of the 500 major companies published in the Exame Melhores e Maiores magazine (2010). For their selection, the start point was an initial list of 375 companies that released their financial statements regarding 2008, elaborated by the Foundation Institute of Accounting, Actuarial and Financial Researches (Fipecafi), responsible for the elaboration of the Melhores e Maiores magazine databank.

From the initial list, the following were discarded: 1) all the cooperatives - because they don't classify in the concept of company (art. 982 of the New Civil Code); 2) companies with no observations regarding the two researched periods: before and after the Accounting SPED (at least one year in each); 3) companies having the absence of observations regarding some explanatory and control variable, in all the years; 4) companies having inconsistent data in regard to the time series, resulting from factors unrelated to the operational activity (billionaire losses recorded in 2008, resulting from operations with derivatives). After this treatment, the final sample of 283 companies participating in such magazine was defined.

Companies that did not published their financial statements with integral price level adjustment had their sales updated by the Exame Melhores e Maiores magazine (2010), based on the average inflation rate showed by the Broad Index of Consumer Prices (IPCA-IBGE). All these values were converted to the currency of purchasing power on December 31, 2009. 
Companies that did not release their results regarding some specific year of the researched period, and had their turnover estimated by the Exame Melhores e Maiores magazine (2010) (single information of cross-section for that year) were excluded from the sample, in view of the possibility of obtaining biased or inconsistent estimators.

\subsection{Operational definition of variables}

The variables used in the research were divided into three groups: dependent variables, interest variable and control variables. Data regarding these variables were extracted from the databank available in the Exame Melhores $e$ Maiores magazine website, and correspond to the information included in the Financial Statements published in the Official Gazette of the states, or in case of limited companies, in the statements sent for the analysis by the Exame Melhores $e$ Maiores magazine (2010).

\section{Dependent variables}

In general, the legal entities are subject to the taxation of their turnover and profit. The gross revenue variable (FAT) used in this study corresponds to the natural logarithm of the gross sales revenue with products and services (InFAT), with the aim of providing the relation with control variables with more linearity.

According to this research objective, the ideal dependent variable would be the taxable profit or the actual profit (determined through additions and exclusions from the net profit of the verification period obtained in the accounting bookkeeping, before the provision for the income tax). However, this variable was not available, and the legal net profit (LLL), verified after discounting the income tax and the social contribution, was used, and therefore with a taxable profit component.

This second dependent variable corresponds to the nominal result of the fiscal year, verified according to the tax legislation (without considering the inflation effects), after discounting the income tax and the social contribution, and the adjustment of interests on the equity capital, if considered as financial expenses. As all the other numerical variables used in the regression (except for those corresponding to an index figure), the values are expressed in million Reals, adjusted to $12 / 31 / 2009$, based on the average IPCA-IBGE variation, allowing a year-on-year comparison.

\section{Interest variable - SPED}

The explanatory interest variable in the study corresponds to the requirement or not of submitting the Digital Accounting Bookkeeping (ECD) - Accounting SPED. It was represented by a dummy variable: 1 , if the company was obliged to submit the Accounting SPED; 0, if not. The coefficient of this variable indicates the variation of turnover/profit declared by companies after the Accounting SPED became obligatory. Once the other explanatory variables were controlled, a significant coefficient indicates the rejection of the null hypothesis of this research: the ECD is not related to the economic-financial results declared by companies (gross revenue and net profit).

\section{Control variables}

To eliminate the effect of the economicfinancial results behavior factors (gross revenue and net profit), control variables related to the companies' business environment were used, as well as to macroeconomic factors. The control variables used were: company size, operational cash flow of the company, wealth created, general indebtedness, activity sector, and Gross Domestic Product (GDP).

For the company size, the natural logarithm of the shareholders' equity (InPL) was used, once the database of the Maiores e Melhores magazine does not provide proxies commonly used in the literature, such as the total assets (CASTRO JÚNIOR, 2008; MOSES, 1987; STUBBEN, 2010). The EBITDA indicator was used as a proxy for the operational cash flow of the company, verified before the income tax calculation, since it corresponds to the "genuine operational capacity 
of generating cash of a company, i.e., its financial efficiency determined by the adopted operational strategies" (ASSAF NETO, 2002, p. 207).

The variable Created Wealth (RC), verified by the arithmetical difference between the sales amount and the inputs paid to third parties added to depreciations, shows the contribution of the company in the Brazilian GDP formation, and therefore represents an important performance indicator. The inclusion of this variable in the regression model was intended for a bigger control on the individual characteristics of companies, such as the management quality that, in a way, could not be captured by the other control variables used. In turn, the General Indebtedness (EG) variable, which corresponds to the sum of the current liabilities (short term debts and obligations, including discounted duplicates) with the non-current liabilities, was used to represent the proportion of total assets of the company financed by creditors. Its value is presented as the percentage in relation to the total adjusted assets.

An activity sector variable was also used, according to the IBGE classification (2009): services, industry and agribusiness. Each sector was represented by a dummy variable, of the binary type, assuming the value 1 , when the company belongs to a certain sector, or 0 , otherwise. In such case, as the qualitative variable has three levels (sectors), two dummy variables were needed to construct the regression model. Wooldridge (2006b) recommends the use of dummy variables of year to eliminate possible macroeconomic effects in the dependent variable (gross revenue). In this study, the GDP - sector (services, industry, and agribusiness) quarterly gross domestic product was used, once the year dummies present a perfect linear correlation with the research interest variable - SPED. Thus, the GDP has a variable that performs a external factor control function that influence the companies' performance.

\subsection{Empirical model of data analysis}

To check the existence of a significant relation between the Accounting SPED and the economic-financial results declared by the sample companies, a modeling consisting of relating the gross revenue and the net profit (declared economic-financial results) was used, in function of the previously defined explanatory and control variables, through a series of longitudinal data (throughout time). As observed by Hill, Griffiths and Judge (2003), when researching the economic behavior of companies throughout time, there is a data time series in cross-section of various economic units. The problem becomes the construction of a statistical model that allows estimations and inferences from such observations, however that capture the individual differences of behavior among the researched companies.

In this research, the technique of regression model for panel data was used, in which the coefficients estimated by the model represent the elasticity of the dependent variable in regard to each of the explanatory and control variables. Upon including the Accounting SPED binary variable into the regression model, it was possible to check whether this variable has statistic significance to explain the variations in dependant variables (gross revenue and net profit).

In order to evaluate the research hypotheses, regression models for panel data were built with random effects (EA), according to the approach introduced by Wooldridge (2006a).

\section{DISCUSSION AND ANALYSIS OF THE RESULTS}

The regression models developed in this research tried to verify whether the revenue and net profit variation (in the period 2008-2009 against 2004-2007) could be explained by the deployment of the Accounting SPED, once the effects of the control variables are eliminated. The estimation models with non-observed heterogeneity had the purpose of controlling the bias of some omitted variable, even if it is not observed. For the estimation of models, the Jarque-Bera normality test of residues was 
conducted, which rejected the hypothesis of normality of errors. However, considering the size of the samples used, it is reasonable to assume that the statistical tests keep their asymptotic properties (not biased and consistent) for the inferences regarding the coefficients of variables used in the models (ANDERSON, SWEENEY, WILLIANS, 2008).

Wooldridge (2006b, p. 436) call the attention to the fact that, when adding a set of annual dummy variables to a regression model, "we cannot estimate the effect of any variable which change along the time is constant". In such situation, the inclusion of a variable with constant variation along the time in a regression would create a problem of perfect multicollinearity (linear relation among independent variables). In this study, a perfect multicollinearity relation was observed among the SPED and dummy variables of the year, once the SPED variable remains constant along the research period, for all the companies. To turn around such limitation, we have decided to use the quarterly GDP per sector (services, industry and agribusiness) variable as the control variable that allows to expurgate possible macroeconomic variations in the revenue/profit results. Thus, the coefficient estimated for this variable represents the revenue/profit variation in function of the GDP.

Initially, a descriptive analysis was conducted to understand the main relations among variables. The revenue response variable (FAT) presented a positive asymmetric distribution, which justifies, once again, its transformation into the logarithmic scale. The $\ln P L$ (shareholders' equity logarithm) variable that represents the company size presented a slight positive asymmetry. Furthermore, it was possible to visualize, in the logarithmic scale, a non-linear relation between the gross revenue (FAT) and the shareholders' equity (PL). An increase of the FAT insofar as the shareholders' equity increased was also observed. These relations were verified also when data were visualize in time (year-on-year). Finally, it was possible to observe the characterization of possible outliers in the sample, identified by the companies Petrobras, BR Distribuidora and Vale.

All the estimated models were submitted to the Breusch and Pagan test, based on the Lagrange's multiplier, described by Greene (2003) and Wooldridge (2006a), to check the existence of non-observed heterogeneity (presence of non-observed effects in the response variables). Tests indicated that the model with nonobserved heterogeneity is the most appropriate to process data ( $\mathrm{p}$-value $<0.001)$. Coefficients were estimated by using the correction of the bias of the covariance matrix proposed by White (1980), providing asymptotically consistent and non-biased estimators (regression with robust errors), even in the presence of eventual problems of heteroscedasticity and autocorrelation (WOOLDRIDGE, 2006a).

The regressions of dependant variables were conducted by using two approaches. In the first approach, all the sample data in an unbalanced panel were used, while in the second approach, the observations regarded as outliers (Petrobras, BR Distribuidora and Vale) were withdrawn, thus showing their possible impacts in the results of the models. The resulting sample was of 274 and 271 companies, respectively. In Table 1, the results of the model regressions with random effects are presented. 
TABLE 1: Regression for the inFAT variable - Random effects

\begin{tabular}{|c|c|c|c|c|c|c|c|c|}
\hline \multirow[b]{2}{*}{ Variable } & \multicolumn{4}{|c|}{ Panel A: Total sample } & \multicolumn{4}{|c|}{ Panel B: Sample without outliers } \\
\hline & Coefficient & Standard Error & P-value & & Coefficient & $\begin{array}{l}\text { Standard } \\
\text { Error }\end{array}$ & P-value & \\
\hline Constant & 5.94840 & 0.35182 & $<0.0000$ & $* * *$ & 6.04970 & 0.32345 & $<0.0000$ & $* * *$ \\
\hline $\ln P L^{\bigotimes}$ & -0.02078 & 0.08986 & 0.8171 & & -0.03827 & 0.07963 & 0.6309 & \\
\hline $\ln P L^{2}$ & 0.02723 & 0.00749 & $<0.0002$ & $* * *$ & 0.02599 & 0.00616 & $<0.0000$ & $* * *$ \\
\hline $\mathrm{RC}$ & 0.00002 & 0.00000 & $<0.0054$ & $* *$ & 0.00005 & 0.00002 & 0.0227 & $*$ \\
\hline EBITDA & 0.00002 & 0.00002 & 0.3838 & & 0.00015 & 0.00004 & 0.0000 & $* * *$ \\
\hline EG & 0.01035 & 0.00187 & $<0.0000$ & $* * *$ & 0.00983 & 0.00169 & $<0.0000$ & $* * *$ \\
\hline GDP & 0.01123 & 0.00206 & $<0.0000$ & $* * *$ & 0.00871 & 0.00194 & $<0.0000$ & $* * *$ \\
\hline SPED & 0.10092 & 0.01351 & $<0.0000$ & $* * *$ & 0.09612 & 0.01337 & $<0.0000$ & $* * *$ \\
\hline Companies-year & & 1321 & & & & & 1303 & \\
\hline adjusted & & $62.40 \%$ & & & & & $9.68 \%$ & \\
\hline Test F & & $315.6660<0.0000$ & & $* * *$ & 433.5960 & & 000 & $* * *$ \\
\hline
\end{tabular}

Source: The authors.

As observed in Table 1, the company size, RC, EG and GDP control variables have statistic significance, when analyzing the results of the model by using the total sample (Panel A). As already verified in the descriptive analysis, the gross revenue logarithm has a non-linear relation with the company size (represented by the logarithm of the shareholders' equity $\ln P L$ ). In this case, a quadratic term was necessary to represent this relation. Among the control variables used, only the EBITDA did not have statistic significance with the gross revenue, when utilized in the total sample.

The estimation of the unbalanced panel for the sample without outliers (Panel B) improved the model adjustment, which presented determination coefficient (adjusted $=0.6968$ ) higher than the unbalanced model using the total sample (and the SPED variable estimator indicated that the average revenue (gross revenue logarithm) after the obligatoriness was higher than in the period before the deployment of the SPED.

In regard to the net profit variable (LLL), the regression models with random effects are shown in Table 2. In these models, 283 companies were used for the total sample (Panel A) and 280 companies for the sample without outliers (Panel B). 
TABLE 2: Regression for the LLL variable - Random effects

\begin{tabular}{|c|c|c|c|c|c|c|c|c|}
\hline \multicolumn{4}{|c|}{ Panel A: Total sample } & \multicolumn{5}{|c|}{ Panel B: Sample without outliers } \\
\hline Variable & Coefficient & $\begin{array}{c}\text { Standard } \\
\text { Error }\end{array}$ & P-value & & Coefficient & $\begin{array}{l}\text { Standard } \\
\text { Error }\end{array}$ & P-value & \\
\hline Constant & 173.4092 & 75.6811 & 0.0221 & * & 221.0706 & 64.3712 & 0.0006 & $* * *$ \\
\hline EBITDA & 0.6306 & 0.0533 & $<0.0000$ & $* * *$ & 0.4656 & 0.0480 & $<0.0000$ & $* * *$ \\
\hline EG & -2.8778 & 1.0810 & 0.0078 & $* *$ & -3.1196 & 0.9957 & 0.0018 & $* *$ \\
\hline S1 & 116.8599 & 50.9683 & 0.0219 & * & 77.9529 & 29.9034 & 0.0092 & $* *$ \\
\hline S2 & -97.0416 & 51.0483 & 0.0575 & $\dagger$ & -48.1369 & 34.6027 & 0.1644 & \\
\hline GDP & -11.2249 & 4.4477 & 0.0117 & * & -9.2432 & 3.5748 & 0.0098 & $* *$ \\
\hline SPED & -53.0506 & 22.8148 & 0.0202 & $*$ & -35.4280 & 20.7623 & 0.0882 & $\dagger$ \\
\hline Companies-year & 1500 & & & & & 1482 & & \\
\hline adjusted & $73.68 \%$ & & & & & $34.85 \%$ & & \\
\hline Test F & 709.2660 & & & $* * *$ & 132.4540 & $<0.0000$ & & *** \\
\hline \multicolumn{9}{|c|}{ Significance levels: ‘ $\dagger 0.1$ (*) $0.05^{(* *)} 0.01^{(* * *)} 0.001$. } \\
\hline
\end{tabular}

Source: The authors.

The results of Table 2 indicate that the EBITDA, EG and GDP control variables had statistic significance in the models for the net profit. In these models, the dummy variables of the economic sector $(\mathrm{S} 1=$ industry, $\mathrm{S} 2=$ service $)$ respectively had statistic significance of $5 \%$ and $10 \%$, considering that the $\mathrm{F}$ test indicated global significance. The agribusiness sector is not represented in the model, since it was used as reference category in the construction of the sector dummies. Individually, such variables also had significant coefficients. The $S 1$ variable coefficient indicates that, keeping the other independent variables fixed, LLL of companies of the industrial sector was in average higher than the LLL of the agribusiness sector companies. On the other hand, the services sector companies registered, in average, a revenue lower than of the agribusiness sector. The EG, GDP and SPED variables had negative coefficient. In regard to the general indebtedness, the signal indicates that the bigger the financial leveraged, the smaller the profit. The same can be concluded in relation to the GDP variable.
The dummy variable SPED had statistic significance in the models of random effects of the two net profit estimation panels, respectively, 5\% and $10 \%$. Its negative coefficient indicates that the net profit (LLL) after the obligatoriness is smaller than in the period before the deployment of the SPED. Differently from the models for gross revenue, the unbalanced panel estimation for the samples without outliers (Panel B) had a poor adjustment, having a determination coefficient $\left(\mathrm{R}^{2}\right.$ adjusted $\left.=0.3485\right)$ smaller than of the unbalanced model using the total sample $\left(\mathrm{R}^{2}\right.$ adjusted $\left.=0.7368\right)$. This means that the influence of companies withdrawn from the sample (Petrobras, BR Distribuidora and Vale) in the model for the net profit is extremely large on the other companies. However, it is possible to observe that the SPED variable was still kept significant in $10 \%(\mathrm{p}$-value $=0.0882)$.

\section{FINAL CONSIDERATIONS}

Considering the relevance of the tax System for the economic and social development 
of the country, in addition to financing the government expenses, the tax collection issue is a subject very relevant for the studies on public administration and social management. Tax evasion has noxious effects on the efficiency and fairness of the tax system, and therefore tax collection polices should focus on detecting and enforcing sanctions to evasion activities, and, on the other hand, it should create incentives to the volunteer compliance with tax obligations (net profit and gross revenue declared by the companies).

This study had the aim of verifying whether the Accounting SPED deployment had any influence on the economic-financial results declared by companies. According to the tax evasion analysis models exposed in the bibliographic review, considering that the SPED increases the effectiveness and efficiency of the tax administration audit mechanisms, an increase of the volunteer compliance by the sample companies was expected, and was confirmed in the research. By empirically verifying alterations in the behavior of companies regarding their tax responsibilities, resulting from the new system to comply with accessory obligations (SPED), this research might provide important subsidies for planning and executing tax collection polices and to fight tax evasion.

The regression model for panel data was considered appropriate to estimate the dependant variables of the research (revenue and net profit), since it allowed the control of the non-observed heterogeneity.

The SPED variable was significant in the two regression models of the InFAT variable (Panels A and B), and the estimated coefficients indicate that, once the effects of other control variables are eliminated, the revenue has positive elasticity in function of the SPED. The consistence of results and the degree of significance observed indicate the efficiency of the estimation model, and allow the conclusion of the existence of a positive relation between the SPED and the gross revenue declared by companies.

In the models estimated for the net profit variable, the SPED showed to be also significant in Panels A (total sample) and B (sample without outliers). However, the variability of the significance degrees and estimation coefficients in both panels perhaps indicated that the model is too fragile to the presence of extreme profit observations. Actually, we expected that the models would face more difficulties to explain the behavior of the net profit, since we can point out that the block of the 500 biggest companies listed in the Exame magazine recorded a loss of $10 \%$ in sales in 2009 , and a growth of $20 \%$ of the profit in the same period. Thus, perhaps the profit is more susceptible to internal management mechanisms, specific for each company, which are not captured by the control variables used in the estimation model. Another possible explanation perhaps is the fact that his proxy was not the most appropriate to represent the profit as one of the variables representative of the economic-financial results declared by companies, which in a way is one of the limitations of this research.

Another limitation of this research is related to the sample used. Since the selection criterion was the availability of data (sample per convenience), this is not a random sample. Therefore, the obtained results cannot be used to make inferences about the researched population.

In regard to the control variables used, we should say that these were also defined because of the availability of data. For instance, the InPL variable was used as a proxy of the companies' size, because there was no information about the total assets of the companies in the database used. Although the models determination coefficients had results indicating the efficiency of the adjustment of the estimated multiple regression equation, it is not possible to ensure that the used variables were sufficient to eliminate all the possible effects of the economy growth (factors external do the company) and of the organic growth (internal factors) of the companies. I.e., it is possible that other control variables, not used in this research, would be relevant to explain the variation of dependent variables.

At last, the empirical investigation conducted in this research allows extension with the use of other control variables. Other samples can be selected, from different databases and periods. Such extensions would be very valuable to check the stability of the results obtained in this study, thus contributing to the analysis of tax policies of imposition. 


\section{REFERENCES}

ALM, J. Uncertain tax policies, individual behavior, and welfare. The American Economic Review, Nashville, v. 78, n. 1, p. 237-245, Mar. 1988.

; MCKEE, M. Audit certainty, audit productivity, and taxpayer compliance. National Tax Journal, Washington, D. C., v. 59, n. 4, p. 801-816, 2006.

ALLINGHAM, M. G.; SANDMO, A. Income tax evasion: a theoretical analysis. Journal of Public Economics, Amsterdam, v. 1, n. 3/4, p. 323-338, Nov. 1972.

ANDERSON, D. R.; SWEENEY, D. J.; WILLIANS, T. A. Estatística aplicada à administraçáo e economia. 2. ed. São Paulo: Cengage Learning, 2008.

ASSAF NETO, A. Estrutura e análise de balanço. 7. ed. São Paulo: Atlas, 2002.

BARBOSA, F. H.; BARBOSA, A. L. N. H. O sistema tributário no Brasil: reformas e mudanças. In: BIDERMAN, C.; ARVATE, P. (Orgs.). Economia do setor público no Brasil. Rio de Janeiro: Elsevier, 2004. cap. 16, p. 290-317.

BERGAMINI JUNIOR, S. Inflação, tributação e competitividade. Revista do BNDES, Rio de Janeiro, v. 8, n. 15, p. 213-246, 2001.

BRASIL. Decreto n. 6.022, de 22 de janeiro de 2007a. Institui o sistema público de escrituração digital - SPED. Disponível em: <http://www. planalto.gov.br/ccivil_03/_Ato2007-2010/2007/ Decreto/D6022.htm>. Acesso em: 15 out. 2009.

. Ministério da Fazenda. Secretaria da Receita Federal do Brasil. Instruçáo Normativa RFB no 787, de 19 de novembro de 2007b. Institui a escrituração contábil digital. Disponível em: <http:// www.receita.fazenda.gov.br/Legislacao/Ins/2007/ in7872007.htm>. Acesso em: 09 jul. 2009.

Ministério da Fazenda. Secretaria da Receita Federal do Brasil. Portaria RFB no 11.211, de 7 de novembro de 2007c. Dispóe sobre o acompanhamento econômico-tributário diferenciado das pessoas jurídicas. Disponível em: <http://www.receita.fazenda.gov.br/Legislacao/ Portarias/2007/portrfb11211.htm>. Acesso em: 09 jul. 2009.

Ministério da Fazenda. Secretaria da Receita Federal do Brasil. Instruçáo Normativa RFB no 926, de 11 de março de 2009. Institui a escrituraçáo contábil digital. Disponível em: <http:// www.receita.fazenda.gov.br/Legislacao/Ins/2009/ in9262009.htm>. Acesso em: 09 jul. 2009.

CAMPELLO, C. A. G. B. Eficiência municipal: um estudo no estado de Sáo Paulo. 2003. 218 f. Tese (Doutorado em Contabilidade) - Faculdade de Economia, Administração, Contabilidade e Atuária da Universidade de São Paulo, São Paulo, 2003.

CASTRO JUNIOR, F. H. F. Apreçamento de ativos com assimetria e curtose: um teste de comomentos com dados em painel. 2008. $178 \mathrm{f}$. Tese (Doutorado em Administração) - Faculdade de Economia, Administração, Contabilidade e Atuária da Universidade de São Paulo, São Paulo, 2008.

COWELL, F. A. Taxation and labour supply with risky activities. Economica, London, v. 48, n. 192, p. 365-379, Nov. 1981.

; GORDON, J. P. F. Unwillingness to pay: tax evasion and public good provision. Journal of Public Economics, Amsterdam, v. 36, n. 3, p. 305-321, Aug. 1988.

CROSS, R. B.; SHAW, G. K. On the economics of tax aversion. Public Finance, Kiel, v. 37, n. 1, p. 36-47, 1982.

DUARTE, R. D. Big Brother fiscal III: O Brasil na era do conhecimento: como a certificação digital, SPED e NF-e estão transformando a gestão empresarial no Brasil. 3. ed. Belo Horizonte: Ideias@work, 2009.

EXAME MELHORES E MAIORES. São Paulo: Abril, jul. 2010. Disponível em: < http://exame. abril.com.br/negocios/melhores-e-maiores/ empresas/maiores/1/2010/vendas $>$. Acesso em: 10 jul. 2010.

FALKINGER, J.; WALTHER, H. Rewards versus penalties: on a new policy against tax evasion. Public Finance Quarterly, [Hungary], v. 19, n. 1, p. 67-79, 1991.

GERON, C. M. S. et al. SPED - sistema público de escrituração digital: percepção dos contribuintes em relação aos impactos de sua adoção. Revista de Educaçáo e Pesquisa em Contabilidade, Brasília, v. 5, n. 2, p. 44-67, 2011.

GREENE, W. H. Econometric analysis. 5th ed. New Jersey: Prentice Hall, 2003. 
HILL, R. C.; GRIFFITHS, W. E.; JUDGE, G. G. Econometria. 2. ed. São Paulo: Saraiva, 2003.

INSTITUTO BRASILEIRO DE GEOGRAFIA E ESTATÍSTICA - IBGE. Contas nacionais trimestrais: indicadores de volume e valores correntes. 2009. Disponível em: <http://www. ibge.gov.br/home/presidencia/noticias/noticia visualiza.php?id_noticia $=1330 \& i d \_p a g i n a=1>$. Acesso em: 07 abr. 2010.

KESSELMAN, J. R. Income tax evasion: an intersectorial analysis. Journal of Public Economics, Amsterdam, v. 38, n. 2, p. 137-182, Mar. 1989.

MAIA, G. L. et al. Custos de conformidade à tributação: uma análise da percepção de gestores e colaboradores em uma empresa estadual de saneamento. ABC Custos - Associação Brasileira de Custos, São Leopoldo, v. 3, n. 3, p. 45-67, set./dez. 2008.

MOSES, O. D. Income smoothing and incentives: empirical tests using accounting changes. The Accounting Review, Sarasota, v. 62, n. 2, p. 358-377, 1987.

OLIVO, R. L. F.; GOZZI, S.; CAVALCANTI, M. A desobediência civil à tributação no Brasil. Revista de Direito, São Paulo, v. 11, n. 13, p. 59-72, 2008.

PENCAVEL, J. H. A note on income tax evasion, labor supply, and nonlinear tax schedules. Journal of Public Economics, Amsterdam, v. 12, n. 1, p. 115-124, Aug. 1979.

POHLMANN, M. C.; IUdÍCIBUS, S. Tributaçáo e política tributária: uma abordagem interdisciplinar. São Paulo: Atlas, 2006.

RICARDO, D.; MENDONÇA, F.; WANDERLEY, J. Um ensaio teórico sobre o crescimento da arrecadação tributária federal no Brasil: aumento dos tributos ou da fiscalizaçáo? Revista Eletrônica de Gestáo Organizacional, Recife, v. 3, n. 3, p. 242-252, 2005.

SAYEG, R. N. Sonegação tributária e complexidade: uma visão multidimensional. RAE-Eletrônica, São Paulo, v. 2, n. 1, p. 1-16, jun. 2003.

SCOTCHMER, S.; SLEMROD, J. Randomness in tax enforcement. Journal of Public Economics, Amsterdam, v. 38, n. 1, p. 17-32, Feb. 1989.
SIQUEIRA, M. L. Um modelo econômico para análise da evasáo fiscal do imposto sobre a renda no Brasil. 2004. 125 f. Tese (Doutorado em Economia) - Universidade Federal de Pernambuco, Recife, 2004.

; RAMOS, F. S. A economia da sonegação: teorias e evidências empíricas. Revista de Economia Contemporânea, Rio de Janeiro, v. 9, n. 3, p. 555-581, dez. 2005.

Evasão fiscal do imposto sobre a renda: uma análise do comportamento do contribuinte ante o sistema impositivo brasileiro. Revista de Economia Aplicada, Ribeirão Preto, v. 10, n. 3, p. 399-424, jul./set. 2006.

SLEMROD, J. Taxation and big brother: information, personalization and privacy in century tax policy. Fiscal Studies, London, v. 27, n. 1, p.1-15, Mar. 2006.

SOUZA, M. C. S.; TANNURI-PIANTO, M. E.; SANTOS, C. A. S. Imposto de importação e evasão fiscal: uma investigação do caso brasileiro. Revista Brasileira de Economia, Rio de Janeiro, v. 62, n. 1, p. 77-93, jan./mar. 2008.

SISTEMA PÚBLICO DE ESCRITURAÇÃO DIGITAL - SPED. [2009]. Disponível em: $<$ http://www1.receita.fazenda.gov.br/sobre-oprojeto/beneficios.htm>. Acesso em: 25 out. 2009.

STUBBEN, S. Discretionary revenues as a measure of earnings management. The Accounting Review, Sarasota, v. 85, n. 2, p. 695-717, Mar. 2010.

VASIN, A. A.; VASINA, P. A. Tax optimization under tax evasion: the role of penalty constraints. Economic Education and Research Consortium - EERC, Moscow, Working paper n. 01/09, p. 1-44, 2002.

WHITE, H. A heteroscedasticity-consistent matrix estimator and a direct test for heteroscedasticity. Econometrica, Oxford, v. 48, n. 4, p. 817-838, May 1980.

WOOLDRIDGE, J. M. Econometric analysis of cross section and panel data. Cambridge: Mit Press, 2006a.

Introduçáo à econometria: uma abordagem moderna. São Paulo: Thomson, $2006 b$. 